\title{
Etnosentrik Eğilim Bağlamında Yerli Üretim Logosunun Satın Alma Niyeti Üzerindeki Rolï
}

\author{
The Role of the Domestic Production Logo on the Intention to Buy in the Context of \\ Ethnocentric Tendency
}

\section{Mevlüt Sedat DÖNMEZ*}

Öz

Bireylerin etnosentrik eğilimleri doğrultusunda markalara yönelik satın alma niyeti geliştirdikleri varsayılmaktadır. Markalar ise ait oldukları menşei ülke bilgilerini bir avantaja çevirme ve bu avantajı tüketicileri ikna etme aracı olarak kullanma gayreti içerisine girmektedir. Bu bağlamda işletmeler ambalajlarında veya iletişim çalışmalarında yerli üretim ifadelerini kullanarak bireylerde kendi ürünlerine yönelik satın alma niyeti oluşturmaya çabalamaktadır. Söz konusu varsayımdan yola çıkan bu araştırma kapsamında etnosentrik eğilim bağlamında yerli üretim logosunun bireylerde satın alma niyeti oluşturmadaki rolü duş jeli ve meşrubat ürün kategorileri çerçevesinde sorgulanmıştır. Anket tekniğinin kullanıldığı ve 316 katılımcı ile gerçekleşen araştırmada aynı zamanda katılımcıların etnosentrik eğilim seviyeleri doğrultusunda ilgili ürün kategorilerine yönelik satın alma niyeti arasındaki farklılıkları da sorgulanmıştır. Sonuçlar doğrultusunda bireylerin etnosentrik eğilimlerinin yerli üretim logosunun kullanıldığ duş jeli ve meşrubat ürünlerine yönelik satın alma niyeti oluşumu üzerinde pozitif yönde etkili olduğu görülürken, etnosentrik eğilim seviyeleri ile bu ürünlere yönelik oluşan satın alma niyeti arasında da anlamlı farklılıkların olduğu sonucuna erişilmiştir.

Anahtar Kelimeler: Etnosentrik Tüketim, Yerli Üretim, Satın Alma Niyeti, CETSCALE, Tüketici Davranışı

\begin{abstract}
It is assumed that individuals develop purchase intentions for brands in line with their ethnocentric tendencies. On the other hand, brands endeavor to turn their country of origin information into an advantage and use this advantage as a means of convincing consumers. In this context, businesses are trying to create purchase intention in individuals for their products by using the expressions of domestic production in their packaging or communication studies. Within this research based on this
\end{abstract}

* Arş. Gör. Dr., Süleyman Demirel Üniversitesi, Halkla İlişkiler ve Tanıtım, Isparta,Türkiye, mevlutdonmez@sdu.edu.tr 
hypothesis, the role of domestic production logo in creating intention to buy in individuals in the context of ethnocentric tendency has been questioned within the framework of shower gel and beverage product categories. This research using questionnaire technique was conducted with 316 participants and differences between the participants' intentions to buy for the relevant product categories in line with their ethnocentric tendency levels were questioned. According to the results, it was observed that ethnocentric tendencies of the individuals had a positive effect on the creation of purchase intention for shower gel and beverage products using the domestic production logo, and it was concluded that there were significant differences between the levels of ethnocentric tendency and purchase intention for these products.

Keywords: Ethnocentric Consumption, Domestic Production, Purchase Intention, CETSCALE, Consumer Behavior

\section{Giriş}

Bireyler ait oldukları toplumsal yapıyı korumak adına etnik merkezci bir yaklaşımda davranış geliştirebilmektedir. Bu bağlamda tüketiciler, tüketim tercihlerinde etnosentrik bir eğilim göstererek yerli üretim ürünlerini tercih etmekte ve böylece ülke ekonomisine katkı sağlama gayreti içerisine girmektedir (Dogi, 2015, s. 86). Bunun yanı sıra etnosentrik eğilim çerçevesinde bireyler yerli üretim ürünlerini tercih ettikleri gibi ithal ürünlere yönelik de bir ön yarg1 geliştirmektedirler (Gašević, Tomašević ve Vranješ, 2017, s. 63).

Bireylerin satın alma niyetleri ile etnosentrik eğilimleri arasındaki ilişkiyi inceleyen birçok araştırma, iki değişken arasındaki pozitif yönlü bir ilişkiyi işaret etmektedir (Klein, Ettenson ve Morris, 1998; Pereira, Hsu ve Kundu, 2002; Javalgi, Khare, Cross ve Scherer, 2005; Klein, Ettenson ve Krishnan, 2005; Papadopoulos, Heslop ve Beracs, 1990). Tüketicilerin vatanseverlik ve milliyetçilik duygularını barındıran etnosentrik eğilimleri doğrultusunda satın alma kararı verebildiğini fark eden markalar ise bireylerin etnosentrik davranışlarını etkilemeye yönelik stratejiler geliştirme çabası içerisine girmiştir. Jean-Noël Kapferer (2008) bu noktada günümüzde birçok markanın Alman arabası, Fransız parfümü gibi ifadelerle ait olduğu ülkenin menşei imajından faydalandığını ifade etmekte ve bu sayede yine markaların tüketicileri satın alma davranışına yönlendirme gayreti içerisine girdiklerini aktarmaktadır (s. 196). Diğer bir ifade ile etnosentrik eğilim doğrultusunda bireyler özellikle ülkelerinde üretilen ürünleri satın alma niyeti içerisine girebilmektedir. Öyle ki, yerli ürünlerin ithal olanlara kıyasla daha düşük kalitede olması durumunda dahi tüketiciler yine de yerli üretim markalarını tercih etme eğilimi gösterebilmekte ve hatta daha yüksek bir ücreti ödemeyi göze alabilmektedir.

Yakın zaman içerisinde Türkiye’de de yerli ürünlerin üretimini ve tüketimini desteklemek amacıyla bir kampanya başlatılmıştır. Bu doğrultuda mal veya hizmetlerin yerli üretim olduğunu gösteren yerli üretim logosu tasarlanarak markalara bu logonun kullanım hakkı verilmiştir. Böylece markalar tüketicilere Türkiye'de üretildiklerini aktarabilmek adına yerli üretim logosunu ambalaj ve iletişim çalışmalarında kullanmaya başlamıştır. Bireylerin etnosentrik eğilimleri ile satın alma niyeti arasındaki ilişkiyi irdeleyen bu araştırma kapsamında yerli üretim logosunun tüketicilerde satın alma niyeti oluşturup oluşturmadığı sorgulanmıştır. Araştırma kapsamında 
yerli üretim logosu kullanan duş jeli ve meşrubat ürün kategorileri seçilmiş ve tüketicilerin sahip olduğu etnosentrik eğilim doğrultusunda bu ürünlere yönelik satın alma niyeti geliştirip geliştirmeyeceği irdelenmiştir. Kolayda örneklem yoluyla belirlenen 316 katılımcıya yüz yüze anket tekniğinin uygulandığı araştırmada ayrıca bireylerin etnosentrik eğilim düzeyleri ile yerli üretim logosunun kullanıldığ 1 duş jeli ve meşrubat ürün kategorilerine yönelik oluşabilecek satın alma niyetleri arasındaki farklılıklar da sorgulanmıştır.

Araştırma kapsamında elde edilen bulgular doğrultusunda ise etnosentrik eğilim bağlamında kullanılan yerli üretim logosunun, duş jeli ve meşrubat ürünlerine yönelik satın alma niyeti oluşturma konusunda pozitif yönde anlamlı bir etki gösterdiği sonucuna erişilmiştir. Bu bağlamda araştırma kapsamında yer alan ve yerli üretim logosunun kullanıldığı ürün kategorileri çerçevesinde, katılımcıların etnosentrik eğilimleri yükseldikçe söz konusu ürünlere yönelik satın alma niyetlerinin de güçleneceği düşünülmektedir. Bunun yanı sıra etnosentrik eğilim düzeyi yüksek olan tüketicilerin ilgili eğilimleri orta ve düşük düzeyde seyreden bireylere göre yerli üretim logolu duş jeli ve meşrubat ürününe yönelik daha güçlü bir satın alma eğilimi gösterdiği; orta düzeyde etnosentrik eğilimli bireylerin ise düşük düzeyde etnosenrik eğilim gösteren bireylere göre daha güçlü bir satın alma niyetine sahip olduğu sonucuna erişilmiştir.

\section{Etnosentrik Tüketim Kavramı ve Etnosentrik Tüketimi Belirleyen Faktörler}

Bireylerin ait oldukları sosyal ve milli toplulukları diğer gruplardan üstün görme eğilimi olarak değerlendirilen etnosentrizm kapsamında insanların toplum içerisinde yaşadığ gruplarla bir özdeşleşme içine girdiği ifade edilmektedir (Dogi, 2015, s. 84). Bu bağlamda etnosentrizm ya da etnik merkeziyetçiliği bireylerin kendi kimliklerini keşfederek herhangi bir gruba ait olma ve içerisinde bulundukları sosyal grupları koruma ihtiyacının bir sonucu olarak tanımlamak mümkündür (Brkicథ, Ćorbo ve Berberović, 2011, s. 47).

Etnosentrizm, bireylerin herhangi bir olay, olgu ya da objeye yönelik zihinlerinde bir tutum veya güçlü bir görüş oluşturmasında etkili bir unsur olarak değerlendirilmektedir (Dogi, 2015, s. 85). Dolayısıyla etnik merkezci anlayışın bireylerin tüketim tercihlerinde de etkili olacağı varsayılmaktadır (Dogi, 2015, s. 86; Sharma, Shimp ve Shin, 1995; Javalgi, Khare, Cross ve Scherer, 2005; Gašević, Tomašević ve Vranješ, 2017, s. 66). Öyle ki, Terence Shimp ve Subhash Sharma (1987) tarafından ortaya atılan etnosentrik tüketim kavramı, tüketicilerin yerel ürünleri tercih ederek ithal edilen ürünlere yönelik satın alma ve tutum açısından ön yargılı oldukları durum olarak özetlenmektedir (Gašević vd., 2017, s. 63). Bu bağlamda Kapferer (2008) markaların çoğu zaman Alman arabası, İsveç saati, Fransız parfümü gibi ait oldukları ülkelerin menşei imajlarından faydalandıklarını ve yerli üretim vurgusunu marka iletişim stratejilerinde kullandıklarını aktarmaktadır (s. 196). Böylece işletmeler ait oldukları coğrafik bölgede tüketicilerin vatansever ve milliyetçi duygularına seslenerek ikna etme çabası içerisinde girmektedir.

Shimp ve Sharma (1987) etnosentrik eğilimleri çerçevesinde satın alma kararı veren tüketicilerin vatanseverlik duygusuyla hareket ederek iç ekonomilerine zarar vermemek adına rakiplerinden daha üstün olmasa dahi yerli üretim markalarını tercih edeceklerini ifade 
etmektedir (s. 280). Benzer şekilde Subhash Sharma, Terence Shimp ve Jeongshin Shin (1995) tarafından gerçekleştirilen araştırma kapsamında vatanseverlik ve muhafazakârlık duyguları yüksek olan tüketiciler ile daha kolektif bir kültür içerisinde yaşayanların tüketim tercihlerinde daha etnik merkezci hareket ettikleri sonucuna erişilmiştir.

Etnosentrik tüketim anlayışı bireylere bir kimlik duygusu atfederek aidiyet duygusu oluşturmaktadır. Bunun yanı sıra ilgili markanın satın alınmasının bireyin ait olduğu grup açısından kabul edilebilir olup olmadığını açıklamaktadır (Shimp ve Sharma, 1987, s. 280).

Tüketicilerin yerli üretim mal ve hizmetleri satın almaya daha istekli olduğu düşüncesi üzerine vurgu yapan etnosentrik tüketim düşüncesinin oluşmasında ve derinleşmesinde rolü olan birtakım unsurlar bulunmaktadır. Bu kapsamda George Balabanis, Adamantios Diamantopoulos, Rene Dentiste Mueller ve T.C. Melewar (2001) etnosentrik tüketimin öncüllerini ve bireylerin etnosentrik eğilimlerini belirlemek amacıyla gerçekleştirdikleri araştırmada vatanseverlik, ulusçuluk ve evrensellik kavramları üzerinde durmuştur. Bu bağlamda vatansever bireylerin kendi uluslarına karşı yoğun bir duygu taşımalarının yanı sıra diğer milletlere de düşmanlık beslemediği görülürken; ulusalcılık içerisinde bulunduğu toplumu diğer ülkelerden daha üstün görme eğilimine karşılık gelmektedir. Diğer bir kavram olan evrensellik başka bir ifade ile kültürel yakınlık ise bireyin diğer uluslara yönelik empati ve anlayışını ifade etmektedir (s. 159-160).

Etnosentrik tüketimi etkileyen diğer unsurlar açısından bakıldığında tüketicilerin eğilimini etkileyen faktörlerin genellikle demografik (yaş, cinsiyet, eğitim ve gelir) (Balabanis, Diamantopoulos, Mueller ve Melewar, 2001; Huddleston, Good ve Stoel, 2001; Sharma vd, 1995; Hult ve Keillor, 1999), sosyo-psikolojik ve sosyo-kültürel farklılıklar (yurtseverlik, muhafazakarlık, kolektivizm, kültürel benzerlik, yaşam tarzı vb.) olarak sıralandığı görülmektedir (Balabanis vd., 2001; Sharma vd, 1995; Watson ve Wright, 2000; Shankarmahesh, 2006; Saffu, Walker ve Mazurek, 2010; Dogi, 2015). Etnosentrik tüketim üzerine gerçekleştirilen çalışmalar incelendiğinde daha yaşlı tüketicilerin genç bireylere göre daha etnosentrik bir tüketimi benimsediği görülmektedir (Balabanis vd. 2002; Sharma vd., 1995). Bu doğrultuda yaşlı tüketicilerin ithal ürünleri daha az tercih ettiği varsayılmaktadır. Eğitim ve gelir durumu olarak bakıldığında ise daha eğitimli ve gelir durumu yüksek olan bireylerin daha az etnosentrik tüketim davranışı içerisinde bulundukları ve dolayısıyla ithal mallara yönelik daha ılımlı oldukları sonucuna erişilmektedir. Başka bir ifadeyle eğitim seviyesiyle tüketicilerin etnosentrik eğilimleri arasında ters yönde bir ilişki olduğu söylenebilir. Bununla birlikte kadın tüketicilerin etnosentrik eğilimlerinin erkeklere göre daha yüksek olduğu sonucu cinsiyetler arasındaki farkı ortaya koyabilmektedir (Javalgi vd., 2005; Klein vd., 2006; Balabanis vd., 2002). Tüm bunların yanı sıra ülkelerin ekonomik gelişmişlik durumunun etnosentrik tüketimde rolü olacağı düşünülmektedir (Javalgi vd., 2005). Srinivas Durvasula, Craig Andrews ve Richard Netemeyer (1997) tüketicilerin etnosentrik tüketim davranışları açısından iki tür ekonomik çevreden bahsetmektedir. Bunlardan birincisi tüketicilerin satın alma tercihlerinde daha az etnosentrik eğilim gösterdiğini düşündüğü gelişmiş ülkelerden oluşmaktadır. Bu ülkeler yabancı ülkelerin ithalatını desteklemekten korkmazken, rekabete açık olmaktadır. Ayrıca yerli ürünlerin kalite standartlarını iyileştirerek ürün yelpazesini genişletmeye önem verir. Bir diğer ekonomik çevre ise tüketim tercihlerinde daha etnosentrik düşünerek yerli üretim ürünlerinin 
satın alınmasını teşvik eden gelişmekte olan ülkelerden oluşmaktadır (s. 76). Bunun yanı sıra Mahesh Shankarmahesh (2006) ülkelerin siyasal yönetimlerinin iç ve dış ekonomi politikalarının da tüketicilerin etnosentrik tüketimlerinde etkili bir unsur olduğunu ifade etmektedir (s. 162).

Yukarıda bahsedilenler doğrultusunda etnosentrik tüketim anlayışının bireylerin tüketim tercihlerinde etkili olacağ 1 ve yerli üretim vurgusu yapan markalara yönelik bir satın alma niyeti oluşturacağı varsayılmaktadır. $\mathrm{Bu}$ varsayım ise bizi araştırmamız kapsamında yerli üretim logosunun tüketicilerde bir satın alma niyeti oluşturup oluşturmadığını incelemeye yönlendirmiştir.

\section{Etnosentrik Tüketim ve Satın Alma Niyeti İlişkisi}

Bireylerin vatanseverlik duygusuyla hareket ederek yerli üretim markalara yönelik satın alım kararı verdiği varsayımı üzerine kurgulanan etnosentrik tüketim birçok açıdan bireyler ve toplumlar arasında farklılık göstermektedir. Saffu ve arkadaşları (2010) bu bağlamda özellikle ülke menşei üzerine kendisini konumlandıran markaların faaliyet gösterdikleri toplumlarda etnosentrik tüketimi güdüleyebilecek iletişim stratejileri geliştirdiğini ifade etmektedir (s. 206). $\mathrm{Bu}$ doğrultuda etnosentrik bireyler tüketim tercihlerinde ülke menşei bilgisine dikkat ederek satın alma niyeti içine girmekte ve yerli üretim markalarını ithal olanlara göre daha taraflı değerlendirmektedir.

Özetle etnosentrik tüketim tüketicilerin vatanseverlik duygusuyla yurt içerisinde üretilen yerli markaları ithal markalara tercih etmesi olarak düşünülmektedir (Saffu vd., 2010, s. 205). Etnosentrik tüketim bağlamında bireyler çoğunlukla kendi ülkelerinde üretilen ürünlerin kalite bakımından yurt dışından ithal edilenlere göre daha iyi olduğuna inanmaktadır (Guo ve Zhou, 2017, s. 164). Hatta bu bağlamda bireyler satın aldıkları ürüne yabancı menşeili bir üründen daha fazla ücret ödemeyi dahi kabul edebilmektedir (Gašević, Tomašević ve Vranješ, 2017, s. 64).

Etnik merkezci düşünmeyen tüketiciler ise satın alma tercihlerinde marka veya ürünün kalite ve performanslarını objektif bir biçimde değerlendirerek bu karşılaştırma neticesinde kararlarını vermektedir (Shimp ve Sharma, 1987, s. 280). Bunun yanı sira etnosentrik bir tüketici de ürünlerin kalitesi, türü gibi faktörlerden dolayı ithal ürünlerin satın alınmasına da sıcak bakabilmektedir (Saffu vd., 2010, s. 206). Örneğin teknolojik bir ürün almak isteyen etnosentrik bir tüketici Japon ürünlerini veya kaliteli bir araba almak isteyen tüketiciler ise Alman arabalarını tercih edebilir.

Terence Shimp (1984) etnosentrik tüketicilerin yerli ve yabancı markalara yönelik tutum ve satın alma niyetlerini incelediği araştırmasında, bireylerin etnosentrik tutumlarının, özellikle kriz dönemlerinde baskın olarak kendini gösterdiği sonucuna erişmiştir. Benzer şekilde Slawomir Smyczek ve Mario Glowik (2011) Polonyalı tüketiciler üzerinde gerçekleştirdikleri Küresel Ekonomik Krizin Bir Sonucu Olarak Polonyal Tüketicilerin Etnosentrizmi (Ethnocentrism of Polish Consumers as a Result Of The Global Economic Crisis) adlı araştırmalarında tüketicilerin kriz dönemlerinde etnosentrik tüketime daha çok yöneldiği sonucuna erişmişlerdir. Bu bağlamda Shimp (1984) tüketicilerin herhangi bir ekonomik kriz durumunda, etnosentrik tutumunun 
vatanseverlik ve milliyetçilik duygularını arttırmasıyla, yerli ürünleri tercih etme eğilimi göstereceğini ifade etmektedir (s. 285). Etnosentrik tüketim anlayışının tüketicilere özellikle kriz dönemlerinde yabancı menşeili ürün almanın yerli ekonomiye zarar verdiğini ve ülke içerisinde iş kaybına neden olacağını düşündürmesi beklenmektedir (Shimp ve Sharma, 1987; He ve Wang, 2015 Balabanis, 2001). Böylece tüketicilerin vatanseverlik duygularıyla yerli üretim markalarını tercih edeceği umulmaktadır. Bu bağlamda Türkiyede de son dönemde yaşanan siyasi krizin ekonomiye olumsuz yansımalarının ardından meydana gelen dolar kuru dalgalanmalarına karşı yerli üretim ve tüketime yönelik devlet eliyle bir kampanya başlatılmış ve bu bağlamda ürünlerin yerli olduğunun belirtilebilmesi açısından Şekil 1'de gösterilen yerli üretim logosu tasarlanmıştır. $\mathrm{Bu}$ doğrultuda yerli üretim olduğunu vurgulamak isteyen markalar tasarlanan logoyu hem ambalajlarında hem de iletişim çalışmalarında ikna edici bir öğe olarak kullanmışlardır.

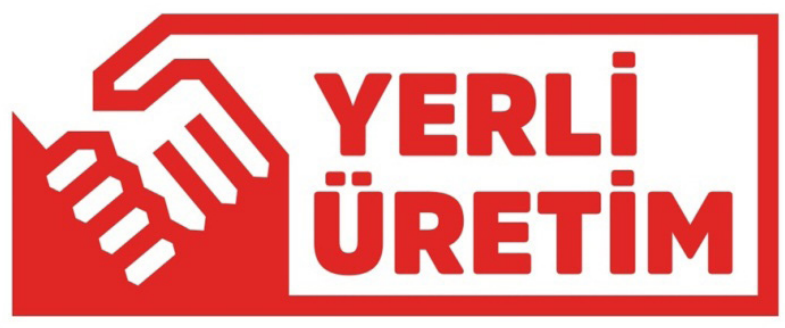

Şekil 1. Yerli Üretim Logosu

Kaynak: “YERLİ ÜRETIMM” logosu (2018, 18 Eylül).

Literatürde etnosentrik tüketim ve satın alma niyeti arasındaki ilişkiyi irdeleyen birtakım araştırmalar bulunmaktadır (Gašević vd., 2017; Arı ve Madran, 2011; Klein vd., 1998; Pereira vd., 2002; Javalgi vd., 2005; Klein vd., 2005; Papadopoulos vd., 1990; Yarangümelioğlu ve İşler, 2014; He ve Wang, 2015; Huang, Phau, Lin, Chung ve Lin, 2008; Saffu vd., 2010). Bu doğrultuda Emin Sertaç Arı ve Canan Madran (2011) gerçekleştirdikleri bir araştırmada farklı etnosentrik seviyedeki tüketicilerin yerli üretim ürünleri satın alma eğilimlerinde de farklılıkların olduğunu tespit etmişlerdir. Bu bağlamda yüksek etnosentrik eğilimi olan bireylerin yerli üretim ürünlere yönelik daha pozitif bir satın alma tutumu içerisinde olduğu sonucuna erişilmiştir. Aynı çalışma çerçevesinde bireylerin yerli üretim ürünleri satın alma eğilimlerinin ürün kategorilerine göre farklılaştığı sonucu ortaya çıkmaktadır. Etnosentrik eğilim ile satın alma niyeti arasında ilişki olduğunu ortaya koyan Dragana Gašević, Dragana Tomašević ve Marija Vranješ (2017) tarafından gerçekleştirilen bir diğer araştırmada ise erkeklerin kadınlara göre yerli ürün tüketmeye daha eğilimli olduğu görülürken eğitim seviyesi yüksek olan tüketicilerin daha az etnosentrik eğilim gösterdiği sonucuna erişilmiştir. Araştırma kapsamında ayrıca gelir seviyesi yüksek olanlar düşük olanlara göre yerli üretim ürünlerinin tüketimine daha yüksek eğilim gösterdiği görülürken yaş faktörü açısından belirgin bir farkın ortaya çıkmadığı görülmüştür. Jill Gabriel Klein, Richard Ettenson ve Marlene D. Morris (1998) ise Çinli tüketicilerin Çin ve Japon ürünlerine yönelik 
tutumlarını inceledikleri araştırmada tüketicilerin etnosentrik eğilimleri ile satın alma tercihleri arasında bir ilişsi olduğu sonucuna erişmişlerdir.

Etnosentrik tüketimin satın alma niyeti oluşturması bağlamında yapılan araştırmalar incelendiğinde ülkeler arasında birtakım farklılıklar ortaya çıktığ 1 görülmektedir. Örneğin, Arun Pereira, Chin-Chun Hsu ve Sumit Kundu (2002) gerçekleştirdikleri araştırmada Çinli tüketicilerin Hintli tüketicilere göre daha etnosentrik temelli bir satın alma niyeti oluşturduğu sonucuna erişmiştir. Rajshekhar G. Javalgi, Virginie Pioche Khare, Andrew C. Gross ve Robert F. Scherer (2005) ise Fransız tüketiciler üzerinde gerçekleştirdikleri araştırmada bireylerin ithal ürünlere yönelik tutumlarını ve satın alma niyetlerini ölçmüşlerdir. Bu bağlamda Fransız tüketicilerin, özellikle menşei ülkesinde nitelikleriyle ün yapmış (Alman arabası, Japon teknolojisi vb.) ürünlere yönelik olumlu bir tutum takınırken satın alma noktasında da olumlu bir tavır geliştireceği sonucuna erişilmiştir. Jill Gabrielle Klein, Richard Ettenson ve Balaji C. Krishnan (2005) ise Çin ve Rusya tüketicileri üzerine yaptıkları araştırmada yabancı ürünlerin daha kaliteli olarak algılandığı ve daha tercih edilebilir olarak değerlendirildiğini görmüştür. Bunun yanı sıra Nicolas Papadopoulos, Louise A. Heslop ve Jozsef Beracs (1990) Macaristan'da gerçekleştirdikleri araştırmada benzer sonuçlara ulaşmışlardır. Derya Yarangümelioğlu ve Didar İşler (2014) Türkiye özelinde etnosentrik tüketim ve marka bağlllığı arasındaki ilişkiyi inceledikleri araştırmalarında tüketicilerin bağlllık derecelerinin etnosentrik eğilimlerine göre farklılık gösterdiği sonucuna erişmişlerdir. Bu bağlamda yüksek etnosentrik tüketicilerin tercih ettikleri markalara daha sadık oldukları görülmektedir.

\section{Araştırma}

Gerçekleştirilen araştırmalar kapsamında etnosentrik eğilim ile satın alma niyeti arasında anlamlı bir ilişkinin varlığından söz edilebilmektedir (Gašević vd., 2017; Arı ve Madran, 2011; Klein vd., 1998; Pereira vd., 2002; Javalgi vd., 2005; Klein vd., 2006; Papadopoulos vd., 1990; He ve Wang, 2015; Huang vd., 2008; Saffu vd., 2010; Watson ve Wright, 2000; Yoo ve Donthu, 2005). Bu bağlamda yerli üretim logosu uygulamasının güncelliği göz önüne alındığında logonun etnosentrik tüketim bağlamında satın alma niyeti oluşturmadaki rolünün irdelenmesinin literatüre katkı sağlayabileceği düşünülmektedir. Diğer açıdan yerli üretim logosunun satın alma niyeti oluşturabilmesi çerçevesinde gerçekleştirilen bu araştırmanın uygulayıcılara da fikir vermesi ve stratejilerine kaynak sağlaması açısından önem taşıdığı varsayılmaktadır.

Nedensel araştırmalarda değişkenler arası iliş̧i irdelenmektedir (Gegez, 2015, s. 48). Bu araştırma kapsamında yerli üretim logosunun katılımcılardaki satın alma niyeti oluşumunda rolü olup olmadığı incelenmektedir. Bireylerin etnosentrik eğilim çerçevesinde kararlarının inceleneceği bu araştırmada ayrıca tüketicilerin etnosentrik eğilim seviyeleri ile yerli üretim logolu ürünlere yönelik geliştirilen satın alma niyeti arasındaki farklılıklar da sorgulanmaktadır. Bu doğrultuda tüketicilerin etnosentrik tüketim bağlamında farklı ürün gruplarında farklı satın alma niyetleri oluşturacağı (Javalgi vd., 2005) gerçeğinden yola çıkarak araştırma kapsamında yüksek ilginlikli ve düşük ilginlikli ürün grubunda yer alan birer adet ürün türü seçilmiştir. 
$\mathrm{Bu}$ bağlamda yüksek ilginlikli ürünleri tüketicilerin satın alım sürecinde üzerinde daha fazla düşündüğ̈̈, satın alım kararının daha zor verildiği ve dikkat gerektiren ürünler olarak değerlendirilmektedir (Pelsmacker, Geuens ve Bergh, 2001, s. 125) Gerçekleştirilen çalışmalar (Ratchford 1987, s. 24; Vaughn, 1986, s. 57; Drewniany ve Jewler, 2008, s. 118) yüksek ilginlikli ürünlerin içerisinde araba, teknik cihazlar, mücevher, giyim ve kozmetik-kişisel bakım ürün kategorilerini göstermektedir. Düşük ilginlikli ürün kategorileri ise bireylerin satın alma tercihlerini daha kolay verdiği, üzerine daha az düşünme zamanı harcadığı, kullanımı kolay mal veya hizmetler olarak tanımlanmaktadır (Wells, Burnett ve Moriarty 1998, s. 234). Bu bağlamda gıda, sıvı sabun, ev temizlik malzemeleri gibi ürünler düşük ilginlikli ürün kategorileri içerisinde değerlendirilmektedir (Ratchford, 1987, s. 24; Vaughn, 1986, s. 57; Drewniany ve Jewler, 2008, s.118). Araştırmada irdelenecek ürün türlerinin belirlenmesinde ise 2018 yllında gerçekleştirilen reklam harcamaları dikkate alınmıştır. Bu doğrultuda Reklamcılar Derneği ile Deloitte firmasının 2019 Mart ayında yayımladığı Türkiye’de Tahmini Medya ve Reklam Yatırımları 2018 Yll Sonu Raporu'na göre en çok reklam veren ilk iki ürün kategorisi gıda ve kişisel bakım - kozmetik olarak belirlenmiştir (Reklamcılar Derneği, 2019, s. 19). Bu bağlamda araştırma kapsamında düşük ilginlikli gıda ürünü içerisinde gösterilen meşrubat ürünü (Ratchford, 1987; Choi, Yoon, Paek ve Reid, 2012) tercih edilirken; yüksek ilginlikli kişisel bakım ürünleri içerisinde görülen duş jeli (Vaughn, 1986; Choi vd., 2012) seçilmiştir.

Araştırma kapsamında Shimp ve Sharma (1987); Gašević vd., 2017; Klein vd., 1998; Pereira vd., 2002; Javalgi vd., 2005; Klein vd., 2006; Papadopoulos vd., 1990; Yarangümelioğlu ve İşler, 2014; He ve Wang (2015); Huang vd. (2008); Ar1 ve Madran (2011); Saffu vd, (2010); Watson ve Wright (2000); Yoo ve Donthu (2005); Armağan ve Gürsoy (2011); Toksarı ve Senir’in (2015) çalışmalarından faydalanılarak aşağıdaki hipotezler oluşturulmuştur;

H1: Duş jeli ürün kategorisinde yerli üretim logosu satın alma niyeti üzerinde istatistiki olarak anlamlı ve yorumlanabilir bir şekilde etkilidir.

H2: Meşrubat ürün kategorisinde yerli üretim logosu satın alma niyeti üzerinde istatistiki olarak anlamlı ve yorumlanabilir bir şekilde etkilidir.

H3: Katılımcıların etnosentrik eğilim düzeyleri yerli üretim logolu duş jeli ürünlerinde satın alma niyeti üzerinde istatistiki olarak anlamlı ve yorumlanabilir bir şekilde fark yaratmaktadır.

H4: Katılımcıların etnosentrik eğilim düzeyleri yerli üretim logolu meşrubat ürünlerinde satın alma niyeti üzerinde istatistiki olarak anlamlı ve yorumlanabilir bir şekilde fark yaratmaktadır.

Spesifik iki ürün grubu özelinde gerçekleştirilmesinden dolayı araştırmanın duş jeli ve meşrubat ürünlerini tüketen bireyler üzerinde uygulanması araştırmanın sınırlılığını oluşturmuştur. Ayrıca zaman ve maliyet kısıtından dolayı araştırma Isparta ili özelinde gerçekleştirilmiştir. $\mathrm{Bu}$ nedenle hem uygulanan ürün grubu açısından hem de tercih edilen örneklem açısından araştırma sonuçlarının tüm Türkiye’ye ve tüm yüksek ve düşük ilginlikli ürün gruplarına genellenmesi mümkün değildir. 


\section{Veri Toplama Yöntemi}

Sadece ulaşılabilir bireylerin araştırmaya dâhil edildiği örneklem türü kolayda örneklem olarak tanımlanmaktadır (Gegez, 2015, s. 266). Bu araştırma kapsamında da kolayda örneklem yöntemi seçilmiştir. Araştırma kapsamında yüz yüze anket tekniği ile katılımcılardan veri toplanmıştır.

Pazarlama araştırmalarında problem çözümüne yönelik yapılan araştırmalarda tipik örnek hacminin 300 ile 500 arasında olması gerekmektedir (Naresh ve Birks, 2000, s. 351). Araştırmada duş jeli ve meşrubat tüketen toplam 370 katılımcı yer almış ancak 54 anketin geçersiz olmasından dolayı araştırma 316 kişi üzerinden değerlendirilmiştir.

Anket tekniğinin kullanıldığı araştırmada katılımcılara 36 adet soru sorulmuştur. Anket soruları 5’li likert ölçeği kullanılarak (1=Kesinlikle Katılmıyorum 2=Katılmıyorum 3=Karasızım 4=Katılıyorum 5=Kesinlikle Katılıyorum) hazırlanmıştır. Anketin ilk bölümünde katılımcılara demografik unsurlara (cinsiyet, yaş, eğitim durumu, medeni durum, çalışma ve gelir durumu) yönelik sorular yöneltilmiştir. Ayrıca bireylerin ürün satın alırken genellikle dikkat ettiği kriteri belirlemek üzere bireylere Herhangi bir ürün satın alacağım zaman genellikle: yerli üretim logosu olan ürünü tercih ederim/yabancı ürünleri tercih ederim/ ürünün menşeine dikkat etmem sorusu sorularak kendilerine en yakın gelen seçeneği işaretlemeleri istenmiştir.

Anketin ikinci bölümünde ise bireylerin etnosentrik eğilim düzeylerini belirlemek amaçlanmıştır. Bu bağlamda tüketicilerin etnosentrik eğilimlerinin belirlenmesinde Shimp ve Sharma (1987) tarafından tüketicilerin etnosentrik eğilim düzeylerinin belirlenmesi amacı ile geliştirilen ve güvenilirlik geçerliliği birçok araştırma (Gašević vd., 2017; Javalgi vd., 2005; Arı ve Madran, 2007; Akın, Çiçek, Gürbüz ve İnal, 2009; Armağan ve Gürsoy, 2011) tarafından kanıtlanmış 17 maddelik Tüketici Etnosentrik Eğilim Ölçeği "CETSCALE (Consumer Ethnocentric Tendency Scale) kullanılmıştır. Araştırma kapsamında ölçeğin güvenilirliğinin test edilmesinde Cronbach Alfa kat sayısından faydalanılmıştır. Bu bağlamda araştırmada Cronbach Alpha değeri 0,928 bulunmuş ve araştırmanın güvenilirliğinin yeterli derecede yüksek olduğu sonucuna varılmıştır.

Araştırma kapsamında tüketicilerin farklı etnosentrik eğilimleri arasında karşılaştırma yapılabilmesi adına bireylerin CETSCALE ölçeğine verdiği yanıtlar üç gruba ayrılarak incelenmiştir. Bu gruplandırmanın gerçekleştirilmesinde beşli Likert ölçeği temel alınmış ve her iki uca ( 1 ve 5) eşit mesafede konumlanan 3 değerinin her iki yanından 0,5 birim alınarak belirlenen aralık oluşturulan gruplandırmanın orta değeri kabul edilmiştir. Bu aralığın altında kalan değer düşük etnosentrik eğilim düzeyi olarak düşünülürken, üzeri ise yüksek etnosentrik eğilim düzeyi olarak belirlenmiştir. Bu kapsamda düşük etnosentrik eğilim şeklinde tanımlanan grubun yer aldığı birinci aralık (1-2,5 aralığı), 17x2,5=42,5 (43 olarak alınmış); orta etnosentrik eğilim biçiminde tanımlanan grubun yer aldığg ikinci aralık (2,5 3,5 aralığ1), 17x3,5=59,5 (4360 olarak alınmış); yüksek etnosentrik eğilim şeklinde isimlendirilen üçüncü grubun bulunduğu aralık ise 61'den başlayıp (3,5-5 aralığı), 17x5=85 üst sınırı ile sınırlandırılmıştır (Arı ve Madran, 2007; Akın vd., 2009; Armağan ve Gürsoy, 2011). 
Anketin üçüncü bölümü olan yerli üretim logolu duş jeli ve meşrubat ürünlerine yönelik satın alma niyetinin ölçülmesinde ise Jill Gabrielle Klein, Richard Ettenson ve Marlene D. Morris (1998) tarafından yerli ve yabancı ürünlere yönelik ürün yargısı ve satın alma niyeti ölçeğinden faydalanılmıştır. Ölçeğin yapı geçerliliği açıklayıcı faktör analizi yöntemi kullanılarak test edilmiştir. Bu analiz uygun alt boyutlara ulaşılana kadar sisteme aykırı olduğu tespit edilen ifadeler çalışmadan çıkarılarak tekrarlanmıştır. Elde edilen sonuçlar aşağıda incelenmiştir.

Tablo 1. Duş Jeli KMO and Bartlett's Test

\begin{tabular}{lcc}
\hline Kaiser-Meyer-Olkin Örneklem Uyum Ölçüsü & & 0,869 \\
\hline \multirow{3}{*}{ Bartlett Küresellik Testi } & $\mathrm{X}^{2}$ & 912,778 \\
\cline { 2 - 3 } & $\mathrm{Sd}$ & 15 \\
\cline { 2 - 3 } & $\mathrm{P}$ & 0.000 \\
\hline
\end{tabular}

Kaiser-Meyer-Olkin Örneklem Uyum Ölçüsü değeri, örneklem hacminin ve elde edilen verilerin çalışma için yeterli düzeyde olduğunu (0.869) ortaya koymaktadır.

Tablo 2. Meşrubat KMO and Bartlett's Test

\begin{tabular}{lcc}
\hline Kaiser-Meyer-Olkin Örneklem Uyum Ölçüsü & & 0,882 \\
\hline \multirow{3}{*}{ Bartlett Küresellik Testi } & $\mathrm{X}^{2}$ & 1145,001 \\
\cline { 2 - 3 } & $\mathrm{Sd}$ & 21 \\
\cline { 2 - 3 } & $\mathrm{P}$ & 0.000 \\
\hline
\end{tabular}

Kaiser-Meyer-Olkin Örneklem Uyum Ölçüsü değeri, örneklem hacminin ve elde edilen verilerin çalışma için yeterli düzeyde olduğunu $(0,882)$ ortaya koymaktadır. Bartlett’s küresellik testi anlamlılık seviyesi $(\mathrm{p}<0.001)$ verilerin çok değişkenli normal dağılımdan geldiğini ifade etmektedir (Otrar ve Argın, 2015). Duş jeline yönelik satın alma niyeti ölçeğinin geçerlilik çalışması açıklayıcı faktör analizi yöntemiyle test edilmiş ve ölçeğin açıkladığı toplam varyans miktarı 60,626 olarak tespit edilmiştir. Dolayısıyla Duş jeline yönelik ölçeğin güvenilir $(0,862)$ ve geçerli olduğu görülmüştür. Meşrubata yönelik satın alma niyeti ölçeğinin geçerlilik çalışması açıklayıcı faktör analizi yöntemiyle test edilmiş ve ölçeğin açıkladığı toplam varyans miktarı 59,813 olarak tespit edilmiştir. Dolayısıyla meşrubata yönelik ölçeğin güvenilir $(0,867)$ ve geçerli olduğu görülmüştür.

\section{Bulgular ve Değerlendirme}

Araştırmaya katılan toplam 316 katılımcı demografik özellikler çerçevesinde incelendiğinde: 127 'si erkek (\% 40,2) 189’u kadın (\% 59,8); 205’i (\% 64,9) 18-23 yaş aralığında, 111’i ise (\% 35,1) 24 yaş ve üzerinde; 10’u (\% 3,2) ilköğretim, 17'si (\% 5,4) lise, 47’si (\% 14,9) ön lisans, 204'ü (\% 64,6) lisans ve 38'i (\% 12) lisans üzeri eğitim durumunda; 43’ü evli (\% 13,6) 273’ü bekar (\% 86,4); 89'u çalışan (\% 28,2) 227'si ise çalışmayan (\% 71,8); 171'i (\% 54,1) 1000 TL ve daha az, 80’i (\% 25,3) 1001-2999 TL arası, 37’si (\% 11,7) 3000-4999 TL arası, 28’i (\% 8,9) ise 5000 TL ve üzeri 
gelire sahip; 117’si (\% 37) yerli üretim logosu olan ürünü tercih edenler, 23’ü (\% 7,3) yabanc1 menşeli ürünleri tercih edenler ve 176 ’sı (\% 55,7) ise ürünün menşeine dikkat etmeyenler olarak gruplanmıştır.

Araştırmanın örneklem hacminin yeterli büyüklükte olması $(n>30)$ ve verilerin normal dağılımdan geldiğini ifade eden basıklık (kurtosis) ve çarpıklık (skewness) katsayılarının istenilen aralıkta olması (-1.96 ile +1.96$)$ analizler için paremetrik test yöntemleri kullanılmasının uygun olduğunu ifade etmektedir (Can, 2014, s. 84-85). Araştırma kapsamında yerli üretim logosunun satın alma niyeti oluşumuna etkisi basit doğrusal regresyon analizi testi ile analiz edilmiştir. Bunun yanı sıra tüketicilerin etnosentrik eğilim seviyeleriyle yerli üretim logosunun satın alma niyeti oluşturması arasındaki ilişkinin ikiden fazla bağımsız grup arasında niceliksel sürekli verilerin karşılattırılmasında Tek yönlü (One way) Anova testi kullanılmıştır.

Tablo 3. Normal Dağılım Tablosu

\begin{tabular}{|l|c|c|c|c|c|c|c|c|c|}
\hline & $\mathbf{N}$ & Minimum & Maximum & Anlamlılık & $\begin{array}{c}\text { Standart } \\
\text { Sapma }\end{array}$ & \multicolumn{2}{|c|}{ Çarpılklk } & \multicolumn{2}{|c|}{ Basıklk } \\
\cline { 2 - 10 } & & & & & & & & & \\
\hline $\begin{array}{l}\text { Etsonetrik } \\
\text { Eğilim }\end{array}$ & 316 & 1,00 & 5,00 & 3,1199 &, 79458 &, 062 &, 137 &,- 297 &, 273 \\
\hline Duş jeli & 316 & 1,00 & 5,00 & 2,6282 &, 90053 &, 418 &, 137 &,- 401 &, 273 \\
\hline Meşrubat & 316 & 1,00 & 5,00 & 2,7611 &, 91179 &, 226 &, 137 &,- 261 &, 273 \\
\hline Geçerlilik N & 316 & & & & & & & & \\
\hline
\end{tabular}

Bu bağlamda $\mathbf{H 1}$ ve $\mathbf{H} 2$ hipotezlerini test etmek amacıyla regresyon değerleri incelenmiştir.

Tablo 4. Etnosentrik Eğilim Bağlamında Yerli Üretim Logosunun Duş Jeli Ürününü Satın Alma Niyeti Üzerindeki Etkisini Belirlemeye Yönelik Basit Regresyon Analizi

\begin{tabular}{|c|c|c|c|c|}
\hline & $\mathbf{R}$ & $\mathbf{R}^{\mathbf{2}}$ & Düzeltilmiş $\mathbf{R}^{\mathbf{2}}$ & Standart Sapma \\
\hline $\begin{array}{c}\text { Duș Jeli Satın Alma } \\
\text { Niyeti }\end{array}$ & 0,720 & 0,519 & 0,518 & 0,625 \\
\hline
\end{tabular}

$(\mathrm{p}<0.05$, Bağımlı değişken: Duş jeli satın alma niyeti, Bağımsız değişken: Etnosentrik eğilim)

Tablo 5. Yerli Üretim Logosunun Duş Jeli Ürününe Yönelik Satın Alma Niyeti Oluşturma Etkisini Belirlemeye Yönelik Basit Regresyon Analizinin Coefficient Tablosu

\begin{tabular}{|l|c|c|c|}
\hline Değişken & Beta & T & Anlamlılık (p) \\
\hline Sabit Sayı & & 0,565 & 0,572 \\
\hline Etnosentrik Eğilim & 0,720 & 18,409 & 0,000 \\
\hline
\end{tabular}


Gerçekleştirilen analiz sonuçları incelendiğinde etnosentrik eğilimin yerli üretim logosunun kullanıldığı duş jeline yönelik satın alma niyetini \% 51,9 oranında açıklamakta olduğu anlaşılmaktadır. Bu doğrultuda iki değişken arasındaki ilişkinin güçlü olduğu söylenebilir $(\mathrm{R}=0,519)$. İstatistiksel anlamda ise anlamlılık düzeyi $(\mathrm{p}<0.05)$ yeterli görülmektedir. Beta değerinin ise pozitif $(\beta=, 720)$ olması etnosentrik eğilimle yerli üretim logolu duş jeli ürününü satın alma arasında pozitif yönlü bir ilişki olacağı anlamına gelmektedir. Diğer bir deyişle bireylerin etnosentrik eğilimleri yükseldikçe yerli üretim logosunun kullanıldığı duş jeli ürününe yönelik satın alma niyetinin de güçleneceği varsayılmaktadır. Bu doğrultuda $\mathbf{H 1}$ hipotezinin kabul edildiği söylenebilir.

Tablo 6. Etnosentrik Eğilim Bağlamında Yerli Üretim Logosunun Meşrubat Ürününü Satın Alma Niyeti Üzerindeki Etkisini Belirlemeye Yönelik Basit Regresyon Analizi

\begin{tabular}{|c|c|c|c|c|}
\hline & $\mathbf{R}$ & $\mathbf{R}^{\mathbf{2}}$ & Düzeltilmiş $\mathbf{R}^{\mathbf{2}}$ & Standart Sapma \\
\hline $\begin{array}{c}\text { Meșrubat Satın Alma } \\
\text { Niyeti }\end{array}$ & 0,666 & 0,443 & 0,442 & 0,681 \\
\hline
\end{tabular}

( $\mathrm{p}<0.05$, Bağımlı değişken: Meşrubata yönelik satın alma niyeti, Bağımsız değişken: Etnosentrik eğilim)

Tablo 7. Yerli Üretim Logosunun Meşrubat Ürününe Yönelik Satın Alma Niyeti Oluşturma Etkisini Belirlemeye Yönelik Basit Regresyon Analizinin Coefficient Tablosu

\begin{tabular}{|c|c|c|c|}
\hline Değişken & Beta & T & Anlamlılık (p) \\
\hline Sabit Sayı & & 2,427 & 0,016 \\
\hline Etnosentrik Eğilim & 0,666 & 15,812 & 0,000 \\
\hline
\end{tabular}

Gerçekleştirilen analiz sonuçları incelendiğinde etnosentrik eğilimin yerli üretim logosunun kullanıldığı meşrubat ürününe yönelik satın alma niyetini \% 44,3 oranında açıklamakta olduğu anlaşılmaktadır. Bu doğrultuda iki değişken arasındaki ilişkinin orta düzeyde olduğu söylenebilir $(\mathrm{R}=0,443)$. İstatistiksel anlamda ise anlamlılık düzeyi $(\mathrm{p}<0.05)$ yeterli görülmektedir. Beta değerinin ise pozitif $(\beta=, 666)$ olması etnosentrik eğilimle yerli üretim logolu meşrubat ürününü satın alma arasında pozitif yönlü bir ilişki olacağı anlamına gelmektedir. Diğer bir deyişle bireylerin etnosentrik eğilimleri yükseldikçe yerli üretim logosunun kullanıldığg meşrubat ürününe yönelik satın alma niyetinin de güçleneceği varsayılmaktadır. $\mathrm{Bu}$ doğrultuda $\mathbf{H 2}$ hipotezinin kabul edildiği söylenebilir. Bu doğrultuda araştırma kapsamında Klein vd., (2005), Pereira vd. (2002), Klein (1998), Shim ve Sharma (1987), Arı ve Madran (2011); Gašević vd. (2017), He ve Wang (2015), Huang vd. (2008), Yoo ve Donthu (2005) çalışmalarıyla örtüşecek sonuçlar elde edilmiştir.

Araştırma kapsamında katılımcıların etnosentrik eğilim düzeyleri ile yerli üretim logosu bulunan duş jeli ve meşrubat ürününü satın alma niyetleri arasında anlamlı farklılıkların olup olmadığı ANOVA testi ile irdelenmiştir. Gerçekleştirilen Anova Testi nihayetinde değişkenler arası $(\mathrm{p}<0.05)$ anlamlı farklılı̆̆a rastlanmıştır. Araştırma kapsamında demografik faktörler ve tüketicilerin ürün satın alırken genellikle dikkat ettiği unsurları tanımlayan soru kapsamında 
anlamlı farklılığa rastlanmamıştır. $\mathbf{H 3}$ ve $\mathbf{H 4}$ hipotezlerini test etmeye yönelik gerçekleştirilen analiz sonucunda ortaya çıkan ilgili farklılıklar ise Tukey testi ile detaylı olarak aşağıda verilmektedir.

Tablo 5. Anova Sonuçları

\begin{tabular}{|c|c|c|c|c|c|}
\hline $\begin{array}{c}\text { Bağımlı } \\
\text { Değişkenler }\end{array}$ & $\begin{array}{c}\text { (I) Etnosentrik } \\
\text { Düzey }\end{array}$ & $\begin{array}{c}\text { (J) Etnosentrik } \\
\text { Düzey }\end{array}$ & I-J & Standart hata & P \\
\hline \multirow{3}{*}{ Meşrubat } & \multirow{2}{*}{ Orta } & Düşük &, $74799^{*}$ &, 10682 &, 000 \\
\cline { 3 - 6 } & & Yüksek &,$- 74531^{*}$ &, 09617 &, 000 \\
\cline { 2 - 5 } & Yüksek & Düşük & $1,49330^{*}$ &, 11561 &, 000 \\
\cline { 3 - 6 } & & Orta &, $74531^{*}$ &, 09617 &, 000 \\
\hline \multirow{3}{*}{ Duş jeli } & \multirow{2}{*}{ Orta } & Düşük &, $72252^{*}$ &, 09985 &, 000 \\
\cline { 2 - 5 } & & Yüksek &,$- 87334^{*}$ &, 08990 &, 000 \\
\cline { 2 - 5 } & Yüksek & Düşük & $1,59585^{*}$ &, 10806 &, 000 \\
\cline { 2 - 5 } & & Orta &, $87334^{*}$ &, 08990 &, 000 \\
\hline
\end{tabular}

Analiz sonuçlarına bakıldığında etnosentrik düzeyi yüksek olan katılımcıların yerli üretim logosu bulunan duş jeline karşı satın alma niyeti gösterme açısından orta düzeyde olanlara göre $\left(, 87334^{*}\right)$ ve düşük düzeyde olanlara göre $\left(1,59585^{\star}\right)$ anlamlı olarak farklılaştığı görülmektedir. Bunun yanı sıra etnosentrik eğilim düzeyi orta olan katılımcıların yerli üretim logosu bulunan duş jeline yönelik satın alma niyeti göstermeleri düşük düzeyde olanlara göre $\left(, 72252^{\star}\right)$ anlamlı olarak farklılaşmaktadır. Dolayısıyla araştırma kapsamında tasarlanan H3 hipotezinin kabul edildiği görülmektedir. Araştırma kapsamında elde edilen bulgulardan yola çıkarak duş jeli markalarının özellikle yüksek etnosentrik eğilime sahip olan tüketicilerde güçlü bir satın alma niyeti oluşturabilmeleri açısından yerli üretim niteliklerini vurgulamalarının önem taşıyacağ düşünülmektedir. Diğer açıdan bu markaların yerli üretim logosunu kullanarak orta etnosentrik eğilime sahip tüketicilerde düşük etnosentrik eğilime sahip tüketicilere göre daha fazla satın alım niyeti oluşturacağı varsayılmaktadır.

Gerçekleştirilen analiz sonucunda etnosentrik eğilim düzeyi yüksek olan katılımcıların yerli üretim logosunun bulunduğu meşrubat ürününe karşı satın alma niyeti gösterme açısından orta düzeyde olanlara göre $\left(, 74531^{\star}\right)$ ve düşük düzeyde olanlara göre $\left(1,49330^{*}\right)$ anlamlı olarak farklılaştığı görülmektedir. Bunun yanı sıra orta düzeyde etnosentrik eğilime sahip olan bireylerin de düşük düzeyde olanlara göre $\left(, 74799^{*}\right)$ anlamlı olarak farklılaştığı görülmektedir. $\mathrm{Bu}$ doğrultuda araştırma kapsamında tasarlanan $\mathbf{H 4}$ hipotezinin kabul edildiği söylenebilmektedir. Elde edilen sonuçlar doğrultusunda yerli üretim logosunu kullanan meşrubat markalarının yüksek etnosentrik eğilime sahip tüketicilerde orta ve düşük düzeyde etnosentrik eğilime sahip tüketicilere göre daha yüksek bir satın alma niyeti oluşturabileceği varsayılmaktadır. Bunun yanı sıra yerli üretim logosunu kullanan meşrubat markaları orta düzeyde etnosentrik eğilime sahip tüketiciler üzerinde satın alma niyeti oluşturmak açısından düşük düzeyde etnosentrik eğilime sahip bireylere göre daha etkili olacağ düşünülmektedir. Bu doğrultuda araştırma kapsamında Arı ve Madran (2011), Saffu vd. (2010), Watson ve Wright (2000), Armağan ve Gürsoy (2011), 
Klein vd., (2012), Pereira vd. (2002), He ve Wang (2015), Huang vd. (2008), Yoo ve Donthu (2005), Toksarı ve Senir (2015) çalışmalarıyla örtüşecek bir sonuç elde edilmiştir.

\section{Sonuç}

Markalar seslendikleri tüketicileri etkileyebilmek, onların vatansever ve milliyetçi yönlerini satın alma niyetine dönüştürebilmek adına yerli üretim vurgusundan faydalanmaktadır (Kapferer, 2008, s. 196). Ait olduğu toplumla özdeşleşerek onu üstün gören bireyler (Dogi, 2015, s. 84) ise sahip oldukları etnosentrik eğilimleri ile satın alma kararını verebilmekte ve kendi ülkelerinin ekonomisine katkı sağlayabilmek adına yerli üretim ürünlerini tercih edebilmektedir (Shimp ve Sharma, 1987, s. 280). Bu açıdan bakıldığında etnosentrik tüketim tercihi, bireylerin vatanseverlik duygusuyla yerli üretim markalarını satın alma eğilimi göstermesi olarak yorumlanabilmektedir (Saffu vd., 2010, s. 205).

Bu doğrultuda ilgili araştırma kapsamında Türkiyede yerli üretim markalarını belirlemek için kullanılan yerli üretim logosunun bireylerde satın alma niyeti oluşturup oluşturmadığı irdelenmiştir. Bunun yanı sıra katılımcıların sahip oldukları etnosentrik eğilim düzeyleri belirlenerek düzeyler arasındaki satın alma niyeti farklılıkları da sorgulanmıştır. Duş jeli ve meşrubat ürünü özelinde gerçekleştirilen bu araştırmada 316 katılımcı üzerinde anket tekniği uygulanmıştır. Bu doğrultuda araştırmanın iki ürün grubuyla sınırlı tutulması ve sınırlı bir örneklem kitlesi üzerinde gerçekleştirilmesinden dolayı sonuçların tüm ürün grupları ve tüm Türkiye tüketicilerine genellemesi gibi bir durum söz konusu değildir.

Araştırma kapsamında elde edilen sonuçlara bakıldığında tüketicilerin sahip olduğu etnosentrik eğilimin yerli üretim logosuna sahip duş jeli ve meşrubat ürününe yönelik satın alma niyetini pozitif yönde etkilediği görülmektedir. Dolayısıyla yerli üretim logosunu kullanan duş jeli ve meşrubat markalarının tüketicilerin sahip olduğu etnosentrik eğilim üzerinde etkili olacağı ve bunun satın alma niyetine yansıyacağı varsayılabilmektedir. Bu bağlamda duş jeli ve meşrubat markalarının tüketicilerin etnosentrik eğilimlerini harekete geçirerek bireylerde satın alma niyeti oluşturabilmeleri için ambalajlarına ve iletişim çalışmalarında yerli üretim logosunu kullanarak bunu sözel anlamda da vurgulamalarının tüketicilerde satın alma niyetini güçlendireceği düşünülmektedir.

Katılımcıların etnosentrik düzeyleri arasındaki farklılıklar araştırma dahilinde irdelenen bir başka noktadır. Gerçekleştirilen analiz doğrultusunda hem yerli üretim logosu bulunan duş jeli hem de meşrubat ürünlerine yönelik satın alma niyetlerinin tüketicilerin etnosentrik eğilimlerine göre benzer farklıklar gösterdiği sonucuna erişilmiştir. Bu bağlamda her iki ürün grubu için de yüksek etnosentrik eğilime sahip tüketicilerin orta ve düşük düzeyde etnosentrik eğilimli tüketicilere göre daha güçlü satın alma niyeti göstereceği görülmüştür. Bunun yanı sıra her iki ürün grubunda da orta düzeyde etnosentrik eğilime sahip bireyler düşük düzeyde olanlara göre daha yüksek bir satın alma niyeti gösterdiği sonucuna ulaşılmıştır. Diğer bir ifadeyle araştırma verilerinden yola çıkarak, yerli üretim logosunu kullanan duş jeli ve meşrubat markalarının yüksek etnosentrik eğilime sahip bireylerde, düşük ve orta düzeyde eğilim gösteren tüketicilere göre daha yüksek 
bir satın alma niyeti oluşturabileceği söylenebilir. Bunun yanı sıra her iki kategori için de orta düzey etnosentrik eğilime sahip olan tüketiciler düşük düzeyde etnosentrik eğilimli olanlara göre daha yüksek bir satın alma niyeti gösterdiği sonucuna erişilmiştir. Bu bağlamda yüksek ilginlikli ve düşük ilginlikli ürün kategorileri arasından seçilen duş jeli ve meşrubat markaları özelinde yorumlandığında her iki ürünü üreten markaların yerli üretim logosunu gerek ambalajlarında gerekse iletişim uygulamalarında kullanarak yüksek etnosentrik eğilimli tüketicilerde daha yüksek bir satın alma niyeti oluşturabileceği varsayılmaktadır. Ayrıca orta düzeyde etnosentrik eğilime sahip bireylerin bu uygulamalardan düşük düzeyde eğilim gösterenlere göre daha fazla etkilenebileceği düşünülmektedir. Bunun yanı sıra araştırma kapsamında bireylerin etnosentrik eğilimlerinin yerli üretim logolu duş jeli ve meşrubat ürünlerine yönelik satın alma niyeti üzerinde etkili olduğu görülürken, bireylerin satın alma niyetlerinin gücünün etnosentrik eğilim düzeylerine göre farklılaştığı sonucuna erişilmiştir. Araştırmanın sonuçlarının tüm Türkiye ve ürün gruplarına genellenememesinden dolayı benzer araştırmaların farklı tüketici ve ürün grupları üzerinde yapılabileceği düşünülmektedir. Buna ek olarak, gelecek araştırmalarda aynı ürün grupları özelinde farklı kültürel niteliklere sahip tüketiciler arasında karşılaştırmaların yapılması önerilmektedir. Bölgesel farklılıkların etkisi düşünüldüğünde farklı demografik ve coğrafik niteliklere sahip bireyler arasındaki farklılıkların irdelenmesi de alana katkı sağlamak açısından faydalı olabileceği düşünülmektedir.

\section{Kaynakça}

Akın, M., Çiçek, R., Gürbüz, E. ve İnal, M. E. (2009). Tüketici etnosentrizmi ve davranı̧ niyetleri arasındaki farklılı̆̆ın belirlenmesinde Cetscale ölçeği. Ege Akademik Bakı̧̧ Dergisi, 9(2), 489-512.

Arı, E. S. ve Madran, C. (2011). Satın alma kararlarında tüketici etnosentrizmi ve menşe ülke etkisinin rolü. Marmara Üniversitesi Öneri Dergisi, 9(35), 15-33.

Armağan, E. ve Gürsoy, Ö. (2011). Satın alma kararlarında tüketici etnosentrizmi ve menşe ülke etkisinin cetscale ölç̧ği ile değerlendirilmesi. Organizasyon ve Yönetim Bilimleri Dergisi, 3(2), 67-77.

Balabanis, G., Diamantopoulos, A., Mueller R. D. ve Melewar, T.C. (2001). The impact of nationalism, patriotism and internationalism on consumer ethnocentric tendencies. Journal of International Business Studies, 32(1), 157-175.

Brkic, N., Ćorbo, M. ve Berberović, D. (2011). Ethnocentrism and animosity in consumer behavior in Bosnia and Herzegovina and implications for companies. Journal of Economics Business, 9(1), 45-61.

Can, A. (2014). SPSS ile bilimsel araşttrma sürecinde bilimsel veri analizi. Ankara: Pegem Akademi.

Choi, H., Yoon, H., Paek, H. ve Reid, L. (2012). 'Thinking and feeling' products and 'utilitarian and valueexpressive' appeals in contemporary TV advertising: A content analytic test of functional matching and the FCB model. Journal of Marketing Communications, 18(2), 91-111.

Dogi, I. C. (2015). Consumer ethnocentrism: A literature review. Agricultural Management/Lucrari Stiintifice Seria I, Management Agricol, 17(2), 84-91.

Drewniany, B. L. ve Jewler, A. J. (2008). Creative strategy in advertising. Boston: Thomson Wadsworth.

Durvasula, S., Andrews, C. ve Netemeyer, R. (1997). A cross-cultural comparison of consumer ethnocentrism in the United States and Russia. Journal of International Consumer Marketing, 9(4), 73-93. 
Gašević, D., Tomašević, D., ve Vranješ, M. (2017). Key factors determining the ethnocentric tendencies of consumers in Serbia. Journal of Sustainable Business and Management Solutions in Emerging Economies, 22(3), 63-73.

Gegez, E. (2015). Pazarlama araştırmaları. İstanbul: Beta Yayınevi.

Guo, G. ve Zhou, X. (2017). Consumer ethnocentrism on product judgment and willingness to buy: a metaanalysis. Social Behavior and Personality, 45(1), 163-176.

He, J. ve Wang, L. C. (2015). Cultural identity and consumer ethnocentrism impacts on preference and purchase of domestic versus import brands: An empirical study in China. Journal of Business Research, 68, 1225-1233.

Huang, Y., Phau, I., Lin, C., Chung, H. ve Lin, K. H. (2008). Allocentrism and consumer ethnocentrism: The effects of social identity on purchase intention. Social Behavior and Personality, 36(8), 1097-1110.

Huddleston, P., Good, L. K. ve Stoel, L. (2001). Consumer ethnocentrism, product necessity and Polish consumers' perceptions of quality. International Journal of Retail \& Distribution Management, 29(5), 236-246.

Hult, G. T. M. ve Keillor, B. D. (1999). A cross-national assessment of social desirability bias and consumer ethnocentrism. Journal of Global Marketing, 12(4), 29-43.

Javalgi, R. G., Khare, V. P., Cross, A. C. ve Scherer, R. F. (2005). An application of the consumer ethnocentrism model to French consumers. International Business Review, 14, 325-344.

Kapferer, N. (2008). The new strategic brand management. USA: Kogan Page Limited.

Klein, J. G., Ettenson, R. ve Morris, M. D. (1998). The animosity model of foreign product purchase: an empirical test in the People's Republic of China. Journal of Marketing, 62(1), 89-100.

Klein, J., Ettenson R. ve Krishnan, B. C. (2005). Extending the construct of consumer ethnocentrism: when foreign products are preferred. International Marketing Review, 23(3), 304-321.

Naresh, K. M. ve Birks, D. F. (2000). Marketing research: An applied approach. ABD: Prentice Hall.

Otrar, M., ve Argın, S.F. (2015). Öğrencilerin sosyal medyaya ilişkin tutumlarını belirlemeye yönelik bir ölçek geliştirme çalışması. Journal of Research in Education and Teaching, 4(1), 391-403.

Papadopoulos, N., Heslop, L. A., ve Beracs, J. (1990). National stereotypes and product evaluations in a socialist country. International Marketing Review, 7(1), 32-47.

Pelsmacker, P. D., Geuens, M. ve Bergh J. V. (2001). Marketing Communications. London: Prentice Hall.

Pereira, A., Hsu, C., ve Kundu, S. (2002). A cross-cultural analysis of ethnocentrism in China, India, and Taiwan. Journal of International Consumer Marketing, 15(1), 77-90.

Ratchford, B. T. (1987). New insights about the FCB grid. Journal of Advertising Research, 27(4), 24-38.

Reklamcılar Derneği. (2019). Türkiye'de Tahmini Medya ve Reklam Yatırımları 2018 Yılsonu Raporu. İstanbul. 10.03.2019 tarihinde https://www2.deloitte.com/content/dam/Deloitte/tr/Documents/ technology-media-telecommunications/2018-turkiyede-medya-ve-reklam-yatirimlari.pdf adresinden edinilmiştir.

Saffu, K., Walker, H. ve Mazurek, M. (2010). The role of consumer ethnocentrism in a buy national campaign in a transitioning country. International Journal of Emerging Markets, 5(2), 203-226.

Shankarmahesh, M. N. (2006). Consumer ethnocentrism: An integrative review of its antecedents and consequences. International Marketing Review, 23(2), 146-172.

Sharma, S., Shimp, T. A. ve Shin, J. (1995). Consumer ethnocentrism: A test of antecedents and moderators. Journal of the Academy of Marketing Science, 23(1), 26-37.

Shimp, T. ve Sharma, S. (1987). Consumer ethnocentrism: construction and validation of the CETSCALE. Journal of Marketing Research, 24, 280-289. 
Shimp, T. A. (1984). Consumer ethnocentrism: The concept and a preliminary empirical test. Advances in Consumer Research, 11(1), 285-290.

Smyczek, S. ve Glowik, M. (2011). Ethnocentrism of Polish consumers as a result of the global economic crisis. Journal of Customer Behaviour, 10(2), 99-118.

Toksarı, M., ve Senir, G. (2015). Menşe ülke etkisinin satın alma kararı üzerindeki etkisi. Uluslararası Sosyal Araştırmalar Dergisi, 8(40), 793-805.

Vaughn, R. (1986). How advertising works: A planning model revisited. Journal of Advertising Research, 26(1), 57-66.

Watson, J. J. ve Wright, K. (2000). Consumer ethnocentrism and attitudes toward domestic and foreign products. European Journal of Marketing, 34(9/10), 1149-1166.

Wells, W., Burnett, J. ve Moriarty, S. (1998). Advertising Principle and Practice. (4. ed.). USA: Prentice-Hall International.

Yarangümelioğlu, D. ve İşler, D. (2014). Marka bağlılı̆̆1 ve etnosentrizm çerçevesinde tüketici satın alma davranışları. Dumlupınar Üniversitesi Sosyal Bilimler Dergisi, 39, 91-109.

Yoo, B. ve Donthu, N. (2005). The effect of personal cultural orientation on consumer ethnocentrism: Evaluations and behaviors of U.S. consumers toward Japanese products. Journal of International Consumer Marketing, 18(1/2), 7-44.

"YERLİ ÜRETIM" logosu. (2018, 18 Eylül). Türkiye Cumhuriyeti Ticaret Bakanlığ Tüketicinin Korunması ve Piyasa Gözetimi Genel Müdürlüğü. 12.03.2019 tarihinde https:// tuketici.gtb.gov.tr/belgelendirme-islemleri/yerli-uretim-logosu adresinden edinilmiştir. 


\title{
The Role of the Domestic Production Logo on the Intention to Buy in the Context of Ethnocentric Tendency
}

\author{
Mevlüt Sedat DÖNMEZ
}

Individuals tend to identify with the society they live in and consider the social group they belong to over other structures (Dogi, 2015, p. 84). As a result of this situation called as ethnocentrism, individuals feel themselves belonging to the group by developing an identity (Shimp and Sharma, 1987, p. 280) and tend to protect that structure (Brkic', Ćorbo and Berberović, 2011, p. 47). Ethnocentric tendency which is assumed to have an effect on the individual's behavior is thought to have a significant effect on the buying preferences of the consumers and the researches support this idea (Dogi, 2015, p. 86; Sharma, Shimp and Shin, 1995; Gašević, Tomašević and Vranješ, 2017, p. 66; Ar1, 2007; Ar1 and Madran, 2011; Klein, Ettenson and Morris, 1998; Pereira, Hsu and Kundu, 2002; Javalgi, Khare and Cross, 2005; Klein, Ettenson and Krishnan, 2006; Papadopoulos, Heslop and Beracs, 1990; Yarangümelioğlu and İşler, 2014; He and Wang, 2015; Huang, Phau, Lin, Chung and Lin, 2008; Saffu, Walker and Mazurek, 2010; Watson and Wright, 1999; Yoo and Donthu, 2005; Armağan and Gürsoy, 2011; Toksarı and Senir, 2015; Akın, Çiçek, Gürbüz and İnal, 2009). In addition, individuals having an ethnocentric tendency see domestic production brands as better quality (Guo and Zhou, 2017, p.164) and prefer domestic production brands to imported ones (Saffu et al. 2010, p. 206). In this direction, brands are trying to persuade consumers by emphasizing country of origin in marketing communication practices (Kapferer, 2008, p. 196).

Demographic factors (Balabanis, Diamantopoulos, Mueller and Melewar, 2001; Huddleston, Good and Stoel, 2001; Sharma et al. 1995; Hult and Keillor, 1999), socio-psychological and socio-cultural characteristics may be influential in the consumer's tendency to ethnocentric consumption (Balabanis et al. 2001; Sharma et al. 1995; Watson and Wright, 2000; Shankarmahesh, 2006; Saffu et al. 2010; Dogi, 2015). When it is considered in terms of countries, while it is seen that the citizens of developed countries, which are open to competition, show a low ethnocentric tendency, individuals of developing countries have a high ethnocentric tendency (Durvasula,

* Res. Asst. Dr., Suleyman Demirel University, Deparment of Public Relations and Publicity, Isparta, Turkey, mevlutdonmez@sdu.edu.tr 
Andrews and Netemeyer, 1997, p. 76). In addition, domestic and foreign economic policies of the political administrations of the countries appear as an effective factor in the ethnocentric consumption of consumers (Shankarmahesh, 2006, p. 162). In this context, especially in times of crisis, ethnocentric tendency levels of consumers are expected to increase and they will be more willing to prefer domestic production brands (Shimp, 1984; Smyczek and Glowik, 2011; Shimp and Sharma, 1987; He and Wang, 2014; Balabanis, 2001). In this context, the "domestic production logo" indicating that the products are domestic production was designed to support domestic production and consumption against the recent exchange rate fluctuations in Turkey.

Within the scope of this research, it is examined whether or not there is an intention to buy in individuals for products with domestic production logo in the context of ethnocentric tendency. In addition, the differences between individuals' levels of ethnocentric tendency and the purchase intention developed for products with domestic production logo are also questioned. Considering that individuals will show different purchase intention for different product groups (Javalgi, Khare, Cross and Scherer, 2005), high involvement shower gel (Vaughn, 1986; Choi, Yoon, Paek and Reid, 2012; Pelsmacker, Geuens and Bergh, 2001) and low involvement beverage product (Ratchford 1987; Choi et al. 2012; Drewniany and Jewler, 2008, p. 118; Wells, Burnett and Moriarty 1998) were preferred by considering the 2018 Advertisement Expenditures Report (Advertisers Association, 2019, p.19).

In this study, which examined the relationship between variables (Gegez, 2015, p. 48), a face-to-face survey was conducted with 316 participants by convenience sampling method in accordance with the recommended sample size of 300-500 (Naresh and Birks, 2000, p. 351). In the survey developed, CETSCALE developed by Shim and Sharma (1987) and Purchase intention scale of Jill Gabrielle Klein, Richard Ettenson and Marlene D. Morris (1998) were used to measure the ethnocentric tendencies of the participants. As a result of the preliminary tests developed, it was found that the parametric test methods of the survey data were appropriate (Can, 2014, p. 84-85) and the relationship between the variables with normal distribution $(-1.96$ and +1.96$)$ was tested by Regreston Analysis (Can, 2014, p. 85; Otrar and Argin, 2015).

As a result of the analysis, it was seen that the ethnocentric tendency had a significant positive effect on purchase intention for shower gel and beverage products with domestic production logo. Therefore, in line with the ethnocentric tendencies of consumers, it is thought that they may show intention to buy shower gel and beverage products with domestic production logo.

Within the research, ethnocentric levels of the participants were determined as high, medium and low and the differences between consumers' ethnocentric tendency levels and the intention to buy shower gel and beverage products using domestic production logo were examined. According to the results of the analysis, it is observed that consumers with high ethnocentric tendency will show stronger purchasing intention for both product groups compared to the medium and low ones. In addition, it was concluded that individuals with medium level ethnocentric tendency in both product groups showed higher purchase intention than those with low level ethnocentric tendency. Based on the findings obtained from the analyzes, it is believed that both shower 
gel and beverage brands emphasize domestic production qualities in order to create a strong purchasing intention especially for consumers with high ethnocentric tendency. On the other hand, it is assumed that these brands will create more purchase intention in consumers with medium ethnocentric tendency than consumers with low ethnocentric tendency by using the domestic production logo.

Keywords: Ethnocentric Consumption, Domestic Production, Purchase Intention, Cetscale, Consumer Behavior 